stone $(Y e n)$. A foreign tradesman who brought it from the South Sea stated it to be the vertebra of a centipede." Seeing that its use here alluded to is nowadays often repeated, we do not hesitate to conclude that this "vertebra of a centipede." was nothing other than the vertebra of a whale. A long series of the cetacean vertebra, especially when it is separate from the skull yet remaining adhered with the fragments of the ribs, would, to the imagination of those crude folks, naturally furnish a ready sketch of a gigantic, marine centipede.

The "Centipede-Whale" of Elian's and Kaibara's descrip. tions are very probably certain species of sharks with the habit of swimming one following another. The reason is that while the fantastic figure of a six-legged sea-serpent, that was cast up on the Orkney in 1808 and subsequently proved to be the shark Selache maxima (Memoirs of the Wernerian Nat. Hist. Soc., Edin., vol. i., Plate XI., I $\delta_{1}$ I), forcibly reminds us of the "Centipede.Whale," piclured in Gesner's "Ilistoria Animalium "(see my letter, l.c.) and in a Japanese work (Hira. zumi, "Morokoshi Kimmôdzui," 1719, tom. xiv. fol. 6, a.), Tanigawa Shisei, the Japanese glossarist (1707-1776), mentions in his "Wakun-no-Shiori" (ed. 1887, 3rd ser., tom. xvi. fol. 8, a.) the "Centipede-Shark" (Mrkadezame), which is doubtless identical with the "Centipede-Whale." That the manner of the natatory movements of some sharks - to which are attributable the words of Elian, "idque conferri posse cum triremi instae magnitudinis, atque per multis pedibus utrinque ordine sitis, tanquam ex scalmis appensis, natare"-should suggest to the mind the active representation of a terrestrial centipede, is well evinced by the Japanese word Mukadebune (i.e. Centipede-Boat), signifying a slender boat with many oars in pairs that have to be moved like the legs of a running centipede (mentioned in Yuasa, "Jîzan Kiclan," 1739 , tom. xv. fol. $12, a$.).

An older description of such a fabulous creature in the Far East, oceurs in the Chinese "History of the Sui Dynasty" (written seventh century, A.D.), and reads thus: "Chin-Lah (Cambodja) produces a fish named $F u$ - $H u$, which resembles Mud-Fel (Monoplerus javanensis, Lacépède, according to Möllen(lorff), but with the bill shaped like the parrot's, and has eight legs ",

When we set apart the more or less allied stories of the Dragon (Chinese, Iung, and Japanese, Tatsu), which very probably originates in the phenomena of waterspout and whirl. pool, ${ }^{1}$ we hardly know from the Far Eastern sources anything like the Sea-Serpent stories so much in circulation in the West. In the Far East, indeed, the Sea-Serpent seems to have totally given place to the Sea-Centipede, hoth having the identical, diverse origins - the back-bone of a whale, the sharks, and some Cephalopods ( $f f$. "Encyc. Brit.," ninth ed., vol. xxi. pp. 608610 , and my letter, lc.). Thus, in China, there prevails a long-established belief in the existence of huge centipedes in the South Sea, very valuable for their flesh and skin, the former tasting like prawn and much superior to beef, and the latter being useful for making drum."

Turning to Japan, we read in the "Konjaku Monogatari" (written by Minamoto-no-Takakuni in the eleventh century, ed. Izawa, tom. xv. fol. 2-7), a narrative of the seven anglers, who killed a centipede about io feet long, that came from anidst a wide sea to combat with a huge serpent, the master of an island. This story of the "Sea-Centipede" is perhaps a prototype of the later but far more popularised legend of Tawara Tôda's slaughter of a monstrous Myriapod, which, the tradition says, used to molest a dragon in Lake Biwa. ${ }^{3}$

7 Effie Road, Walham Green, September i7.

\section{Kumariusu Minakata.}

${ }_{1}^{1}$ For similar misconceptions current among the Arabs, vide "Encjc. Brit." l.c., p. 6ro.

2 The first description of such a gigantic centipede occurs in a poem by Koh Hung (circa. 254-334 A.D.). In the year 745 a centipede was found drowned by sea-tide on a coast of Kwang-Chau, and a man was fortunate enough to secure $120 \mathrm{kin}$ weight of edible flesh by opening its "claws" ""Yuen.kien-lui-ban," 1701, tom. cdxlix. ful. 11, a.). Here, the said "claw" would seem no other than the shark's fin, which in recent times bas become the article of commercial importance with the Chinese. Even in the Imperial (Geography ("Ta-Tsing-i-tung-chi," tom. cccliv. fol. 19, b.), compiled so lately as the eighteenth century, a similar centipede is described
as native to Anam, which Tanigawa (l.c.) happily identifies with his "Centipede-Shark.

3 The latter story is first recorded in "Taiheiki" (written fourteenth century, lib. xv. ch. 3), although its hero flourished in the tenth century (for its brief account see Mr. E. Gilbertson's article in the Trans, and Proc. Jap i Soc., London, $18 q 8$, vol. iv., part ii., p. 115). Kyokutei Bakin, in his "Shichiya-no-Kurn "(18 ro, ch. "V.), gives an exhaustive account of this
tradition, but does not refer to the "Sea-Centipede " story quoted above. NO. I 5 I I, VOL. 58]

\section{The Moon's Course.}

THE moon's unique course was not known, in J. Fergusson's time, to be so peculiar as it now appears; for only five other satellites were then known, but now we know twenty, and stilk no other that has a path always concave to the sun.

It arises, of course, from her being more pulled by the sun than by the earth. All the others are more pulled by their primaries than by the sun. The distance from our earth where she balances the sun is but $1 / 569$ th of the sun's. But the moon's mean distance is fully a 386 th of the sun's. The dise tance from Jupiter where he balances the sun is a 33 rd of his own. That from Saturn is over a 6oth of his own distance. That from Uranus a $155^{\text {th }}$; from Neptune a 140 th ; but from Mars only a 17 foth ; and in every case their furthest satellites are much nearer. Our moon's form of path is quite unique in the universe, so far as known.

25 Claremont Square, London, N., October 1o.

\section{A Simple Method of Making Light Mirrors.}

THF following description of a simple and inexpensive methcd of making optically perfect mirrors for galvanometers and similar instruments will, I think, be of interest to many of your readers.

Strips of French plate-glass, about $5 \mathrm{~mm}$. thick and $20 \mathrm{~mm}$. long, are well silvered and carefully polished with rouge. The silvered strip is placed upon edge on a flat stone or other firm support, and a light blow is struck with the edge of a hammer a little distance back from the silvered face. If the blow is well directed, a chip of glass of circular or elliptical form will be broken out. The nearer the edge the blow is struck the thinner the mirror will be. Of course not every blow will produce a good mirror, but with a little practice a strip ro centimetres long should yield a dozen good mirrors, of assorted weights and sizes, which may be cemented to a card and put away in a box for use as occasion requires. Since the silver surface is exposed, it will tarnish in time ; but as the expense and trouble involved in making the mirrors is so slight, and the definition given by them when new is so perfect, one can afford to renew them once a year if necessary. The method of silvering mirrors given in the "Encyclopredia Britannica" gives a surface well ada pted to this purpose.

Knox College, Galesburg, Illinois, September 17.

\section{Animals and Poisonous Plants.}

WHEN visiting lately the herbaceous department in the Royal Botanic Gardens, Regent's Park, I noticed that nearly all the berries had disappeared from the deadly nightshade, Atropa belladonna, the calyx being left untouched. The foreman of the herbaceous department told me that he believed they had been eaten by blackbirds, which are very active in the bushes; also that the seeds of Datura stramonium are eagerly devoured by mice. Can any of your readers confirm this statement of animals feeding on poisonous plants? In Nature Notes for October, I notice a statement of a report that wild rabbits feed on the leaves of the bella donna.

Alfred W. BexNett.

\section{Crannoges in Estuaries.}

REFERRING to the notices on this subject in NATURE of September 15 and 29 , I beg to say that, in 1879 , I discovered a crannoge constructed on a bed of peat, below high-water mark, in Ardmore Bay, Co. Waterford. It was at the mouth of a small stream.

The diameter of the enclosure was about 100 feet. It was surrounded by a double fence of massive piles, apparently sharpened with the stone axe. The interior contained mortised beams and cleft panels of the dwelling, and portions of the wattled partitions, traces of which covered the enclosed area in the form of pointed stakes whose ends remained in the peat.

The kitchen midden contained bones of horse, ox, goat, pig, and red deer, the usual bill of fare found in the raths of the country.

A paper on this crannoge was published in the Proceedings of the Royal Irish Academy, December 1880 , and the site has been visited by Prof. Boyd Dawkins. It is covered by every tide, and the crannoge is now almost obliterated.

Cappagh, Fermoy, October 1. 